\title{
Are seasonal calving dynamics forced by buttressing from ice mélange or undercutting by melting? Outcomes from full-Stokes simulations of Store Glacier, West Greenland
}

\author{
J. Todd and P. Christoffersen \\ Scott Polar Research Institute, University of Cambridge, Cambridge, UK \\ Correspondence to: J. Todd (jat71@cam.ac.uk) \\ Received: 5 June 2014 - Published in The Cryosphere Discuss.: 2 July 2014 \\ Revised: 30 September 2014 - Accepted: 13 November 2014 - Published: 16 December 2014
}

\begin{abstract}
We use a full-Stokes 2-D model (Elmer/Ice) to investigate the flow and calving dynamics of Store Glacier, a fast-flowing outlet glacier in West Greenland. Based on a new, subgrid-scale implementation of the crevasse depth calving criterion, we perform two sets of simulations: one to identify the primary forcing mechanisms and another to constrain future stability. We find that the mixture of icebergs and sea ice, known as ice mélange or sikussak, is principally responsible for the observed seasonal advance of the ice front. On the other hand, the effect of submarine melting on the calving rate of Store Glacier appears to be limited. Sensitivity analysis demonstrates that the glacier's calving dynamics are sensitive to seasonal perturbation, but are stable on interannual timescales due to the strong topographic control on the flow regime. Our results shed light on the dynamics of calving glaciers and may help explain why neighbouring glaciers do not necessarily respond synchronously to changes in atmospheric and oceanic forcing.
\end{abstract}

\section{Introduction}

Recent studies show accelerating net mass loss from the Greenland Ice Sheet (GrIS) (Rignot and Kanagaratnam, 2006; Howat et al., 2007; Khan et al., 2010), raising concerns about its future response to changing global climate and the impact this might have on global sea level. The two factors which govern this loss are (1) an overall negative surface mass balance stemming from intensified surface melting in the ice sheet's ablation zone (Hanna, 2005; van den Broeke et al., 2009; Enderlin et al., 2014) and (2) faster rates of ice discharge through calving glaciers which terminate in fjords (Luckman and Murray, 2005; Howat et al., 2005; Rignot and Kanagaratnam, 2006; Howat et al., 2007). The latter (dynamic) mechanism accounted for $\sim 67 \%$ of the total net ice loss in 2005 (Rignot and Kanagaratnam, 2006), but less in recent years (Enderlin et al., 2014), highlighting the sensitivity of Greenland's marine-terminating glaciers to the transient pulse of warm Atlantic water flowing into many of Greenland's fjords over the last decade (Holland et al., 2008; Straneo et al., 2010; Christoffersen et al., 2011).

Owing to the advancement of surface mass balance models over the last two decades (Hanna, 2005; Box et al., 2006; van den Broeke et al., 2009; Enderlin et al., 2014), surface mass balance is well represented in global sea level predictions (IPCC, 2013). The rapid dynamics associated with sudden increases in the discharge of ice into fjords by marineterminating glaciers are, on the other hand, complex and poorly understood, and their relationship with climate remains elusive and is so far unconstrained (IPCC, 2013). The main processes involved in rapid dynamics are fast glacier flow and calving, i.e. the mechanism whereby pieces of ice and bergs break off glaciers terminating in water. These processes are complex because they interact with and respond to atmospheric as well as oceanic forcing effects. As such, calving and its associated dynamics comprise one of the most significant uncertainties in predictions of future ice sheet mass balance and sea level change.

While atmospheric processes were previously thought to be the main driver of rapid ice sheet dynamics (Zwally et al., 2002), recent studies point to warm water in coastal currents as the main forcing of mass loss by discharge (Holland et al., 2008). The rapid acceleration of Jakobshavn Isbræ, 
from $\sim 4000 \mathrm{~m} \mathrm{a}^{-1}$ in 1995 to $\sim 17000 \mathrm{~m} \mathrm{a}^{-1}$ in 2012 , is clearly linked to the continuing retreat of the calving ice front over this period (Joughin et al., 2012, 2014), and it has been hypothesised that submarine melting plays a crucial role in driving this retreat (Holland et al., 2008; Motyka et al., 2010). Spaceborne tracking of calving fronts also shows that recent glacier retreat along the East Greenland coastline has been widespread and synchronous below $69^{\circ} \mathrm{N}$, but largely absent at higher latitudes, where coastal water is much colder (Seale et al., 2011). This suggests that these glaciers are retreating in response to changes in the ocean system. Warmer fjord water increases the rate of submarine melting of the calving terminus. This effect is further amplified by atmospheric processes; buoyant proglacial plumes, driven by the delivery of surface meltwater to the terminus by the subglacial hydrological system, are capable of significantly increasing melt rates (Jenkins, 2011). Undercutting of calving ice fronts by submarine melting should, in addition, amplify calving rate due to the stress response (O'Leary and Christoffersen, 2013).

The formation of ice mélange, a rigid mixture of icebergs and bergy bits, held together by sea ice, henceforth referred to simply as mélange, may also play an important role with regard to rapid ice sheet dynamics (Sohn et al., 1998; Joughin et al., 2008). Data from Jakobshavn Isbræ indicate a complete cessation of calving when the glacier is buttressed by mélange, a response that may explain why the glacier advances by up to $5 \mathrm{~km}$ in winter (Amundson et al., 2008) and why the glacier retreats suddenly when the mélange disintegrates (Joughin et al., 2008). A similar correspondence between mélange clearing date and increasing calving rate has been found for a number of glaciers, including those near Uummannaq in West Greenland (Howat et al., 2010). Walter et al. (2012) used changes in velocity observations and a force balance technique to infer a buttressing stress of 30-60 kPa exerted by mélange onto the terminus of Store Glacier. This buttressing effect and the effect of submarine melting (Xu et al., 2013) appear to be crucial for the calving dynamics of this glacier. However, temporal correlation is insufficient evidence to confidently attribute seasonal calving retreat to either the collapse of ice mélange or submarine melting. This highlights the need for numerical modelling to attempt to partition these effects.

In this paper we present results from a numerical model developed using the open-source finite-element (FEM) modelling package, Elmer/Ice, with newly implemented calving dynamics. Theoretical consideration of the calving process indicates the importance of the near-terminus stress field in controlling the propagation of crevasses and the detachment of icebergs (Nye, 1957; van der Veen, 1998a, b; Benn et al., 2007a, b). Linking calving to crevasse propagation and stress in this way provides a useful and physically based framework for investigating calving in numerical models of glacier dynamics. Here, we implement a calving model based on the penetration of both surface and basal crevasses (Nick et al., 2009,2010 ), and incorporate the full stress solution into the

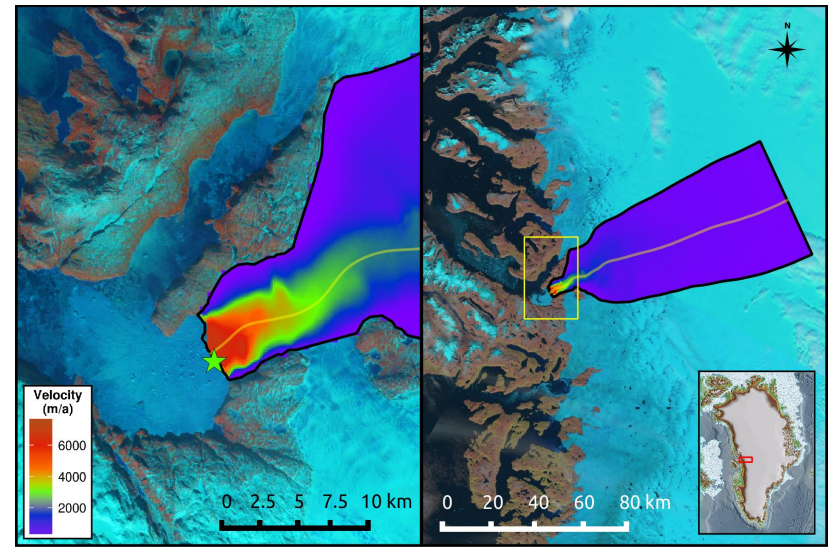

Figure 1. Store Glacier in Ikerasak Fjord, Greenland. Colour scale shows summer velocity $\left(\mathrm{m} \mathrm{a}^{-1}\right)$ from the MEaSUREs project (Joughin et al., 2011). The yellow line indicates the flow line used in this study, and the green star indicates the location of the main proglacial plume forming where subglacial water is discharged into the fjord.

crevasse depth criterion, after Nye (1957). We use this model to investigate the seasonal dynamics of Store Glacier, a fastflowing outlet glacier near Uummannaq in West Greenland, which experiences a large seasonal variability in dynamics and front position (Howat et al., 2010), but has been interannually stable for at least four decades (Weidick et al., 1995; Howat et al., 2010, p. C41). The stable, seasonal calving dynamics of Store, along with the recent discovery of a $28 \mathrm{~km}$ long trough behind the terminus, extending $900 \mathrm{~m}$ below sea level, make this glacier an ideal target for stability analysis as well as process study.

To examine the calving process, we focus on the calving front's position and seasonal fluctuation. We investigate the effects of submarine melting, mélange buttressing and glacier geometry on calving, with the aim of identifying the role of each mechanism in driving the observed seasonal variability at the front. We find that mélange is likely to be the primary driver, and that submarine melting plays a secondary role. We also find that the topographic setting of Store Glacier is responsible for its observed stability.

\section{Store Glacier}

Store Glacier, henceforth referred to as Store, is a fastflowing marine-terminating outlet glacier located in Ikerasak Fjord, near Uummannaq in West Greenland (Fig. 1). The glacier drains an area of $35000 \mathrm{~km}^{2}$ and is $5 \mathrm{~km}$ wide at the terminus, where surface velocity reaches $\sim 6600 \mathrm{~m} \mathrm{a}^{-1}$ (Joughin et al., 2011). The location of the terminus coincides with a bottleneck in fjord width (Fig. 1), as well as a pronounced basal pinning point (Fig. 2), suggesting that fjord topography may play an important role in calving dynamics. 


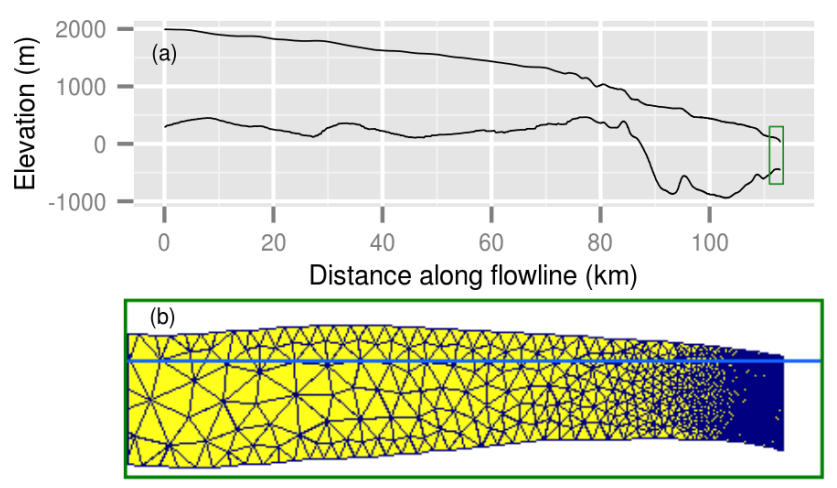

Figure 2. (a) Surface and basal geometry of central flow line used in this study. (b) Model mesh of region outlined by green box in (a). The blue line represents sea level.

In terms of climate, data from the Regional Atmospheric Climate Model (RACMO) suggest that $\sim 2 \mathrm{~km}^{3}$ of meltwater forms on the surface of Store between June and August (Ettema et al., 2009). Recent modelling work (Xu et al., 2013) shows that submarine melting at the terminus may occur at rates of $8 \mathrm{~m} \mathrm{~d}^{-1}$ in summer because a large proportion of runoff is discharged subglacially into Ikerasak Fjord. The latter is established from observations, which show upwelling of dirty, subglacially derived meltwater near the centre of the calving ice front during summer months (Chauché et al., 2014) (Fig. 1). The high melt rates are caused by entrainment of warm ambient fjord water into buoyant meltwater plumes, which rise rapidly in front of the glacier, from a depth of $490 \mathrm{~m}$ below sea level due to forced convection (Jenkins, 2011; Chauché et al., 2014). The glacier is buttressed by a rigid proglacial mélange, which is typically present from late January or early February to the end of May (Howat et al., 2010). When present, this rigid ice mélange has been shown to exert a significant backstress on the calving terminus of Store (Walter et al., 2012).

Store exhibits characteristic seasonal variabilities in terms of calving front position and velocity (Howat et al., 2010). Estimates of the terminus velocity of Store differ depending on where and when data were obtained. The most recently collected TerraSAR-X data, obtained from NASA's MEaSUREs project (Joughin et al., 2011), measure a peak velocity of $6600 \mathrm{~m} \mathrm{a}^{-1}$ at the calving front with a seasonal variability of $\sim 700 \mathrm{~m} \mathrm{a}^{-1}$. Howat et al. (2010) measured velocities a few kilometres behind the terminus and found values ranging from 2500 to $4200 \mathrm{~m} \mathrm{a}^{-1}$ between 2000 and 2010 . Howat et al. (2010) also tracked changes in front position through time, finding a seasonal variability of at least $\sim 500 \mathrm{~m}$, when averaged across the width of the terminus. This is consistent with time-lapse photography showing seasonal advance of $\sim 1 \mathrm{~km}$ near the central flow line (J. Box, personal communication, 2014).

\section{Methods}

In this work, we use Elmer/Ice in a 2-D configuration to model the central flow line of Store. The modelled flow line is $113 \mathrm{~km}$ long and covers the region from the $100 \mathrm{~m} \mathrm{a}^{-1}$ ice velocity contour to the calving front (Fig. 2a). The flow line was produced using velocity vector data from the MEaSUREs project (Joughin et al., 2011).

We use a 2-D modelling framework in which both calving front and grounding line evolve freely through time. Whereas the representation of processes in 2-D requires parameterisation of key out-of-plane effects, as explained below, it is a practical first step which will guide and help the future implementation of calving processes in 3-D.

\subsection{Elmer/Ice dynamics}

Elmer/Ice is a finite-element model which solves the Stokes equations and uses Glen's flow law as a constitutive stressstrain relation (see Gagliardini et al., 2013, for details). The finite-element approach is a flexible solution which allows us to vary the spatial resolution of the model and thereby focus on the dynamics at the calving ice front (Fig. 2b). Because we are principally interested in capturing processes at the calving terminus, we adopt a spatial resolution which varies from $250 \mathrm{~m}$ in the upper region of the glacier to $20 \mathrm{~m}$ near the terminus (Fig. 2b). The model evolves through time with a time step of 1 day.

Temperature is an important factor in the stress-strain relationship of ice (Cuffey and Paterson, 2010). However, near the terminus, which is our region of interest, extensive crevassing makes the implementation of temperature difficult. The ability of subglacial meltwater to penetrate upwards through basal crevasses, as well as the effect of air circulation in surface crevasses, is likely to significantly affect the temperature profile of the ice. Due to these complications, and the lack of observations to constrain ice temperature, we assume for the sake of simplicity that the glacier is isothermal at $-10^{\circ} \mathrm{C}$.

Because basal friction exerts a critical control on the dynamics of fast-flowing glaciers in general, we first use the adjoint inverse method (Gillet-Chaulet et al., 2012) to identify the basal friction profile which results in surface velocity as observed along the flow line. The result of the inverse method is a profile for the basal friction parameter $\left(\beta^{2}\right)$ which is related to basal velocity $\left(U_{\mathrm{b}}\right)$ and basal shear stress $\left(\tau_{\mathrm{b}}\right)$ by the relation (MacAyeal, 1992)

$\tau_{\mathrm{b}}=\beta^{2} U_{\mathrm{b}}$

To integrate seasonal variation in ice flow in response to seasonal change in basal friction, we run the inverse model for both the summer and winter observed velocity profiles, thereby obtaining two basal friction profiles. A seasonal variability in ice flow, very similar to what is observed in real- 
ity, is imposed by varying the basal traction coefficient sinusoidally between summer and winter values.

\subsection{Boundary conditions}

Initial surface elevation along the modelled flow line is prescribed from the GIMP DEM product (Howat et al., 2014). The bed profile is obtained from airborne geophysical surveys carried out by the Greenland Outlet Glacier Geophysics (GrOGG) project and NASA's Operation IceBridge (https: //espo.nasa.gov/missions/oib/). We use a mass-conservation algorithm similar to that of McNabb et al. (2012) to constrain ice thickness and bed topography in the heavily crevassed region of fast flow near the terminus, where radar data are sparse.

Ice thickness evolves through time according to the mass continuity equation (Cuffey and Paterson, 2010), and we add and subtract mass according to RACMO surface mass balance data averaged between 1985 and 2008. The ice surface is treated as a stress-free boundary, as we assume atmospheric pressure to be negligible. At the ice base, friction is prescribed through inverse methods as described above, except under the floating tongue, which, when it exists, is a frictionless free surface. At the calving terminus, we apply an external pressure equal to the hydrostatic pressure from seawater (see Eq. 5 below). Above sea level, atmospheric pressure is neglected.

We simulate the seasonal advance and retreat of Store's floating tongue using an implementation of grounding line dynamics developed by Favier et al. (2012). The grounding line algorithm compares external water pressure and ice overburden pressure to detect where the glacier is floating, and modifies basal friction accordingly.

\subsection{New scheme for implementation of flow convergence}

Similar to most outlet glaciers, Store undergoes significant lateral narrowing as ice flows from catchment to coast. As such, it is important that dynamic effects from sidewall drag (Raymond, 1996) and ice convergence (Thomas et al., 2003) are accounted for.

Gagliardini et al. (2010) implemented a parameterisation for sidewall friction in Elmer/Ice, and we use it here. The issue of ice convergence in full-Stokes 2-D models, however, has thus far received little attention from the glacier modelling community. Here, we have developed a routine which adds flux sources to elements along the flow line, corresponding to the downstream narrowing of the glacier. We derive a flux convergence term (see Supplement) and add it to the Stokes incompressibility equation (Eq. S1 in the Supplement), such that

$\nabla \cdot \boldsymbol{u}=-\frac{\mathrm{d} W}{\mathrm{~d} x} W^{-1} u_{x} A$ where $\boldsymbol{u}$ is the velocity vector, $W$ is glacier width, $u_{x}$ is the along-flow component of velocity and $A$ is the area of the element.

This convergence term represents an important 3-D effect, ensures that mass balance is maintained throughout the model domain, and allows for realistic evolution of mass and momentum near the terminus. We note that this prescribed flux convergence differs from implementation of flow convergence in earlier work with flow line models (e.g. Gladstone et al., 2012; Cook et al., 2014), where the additional mass is added as an input to the surface mass balance. Although the latter will result in correct flux, it neglects the direct effect of the additional flux on the velocity field and may consequently underestimate velocity change while overestimating elevation change.

\subsection{Numerics for implementing calving}

We implement the crevasse-penetration calving criterion (Benn et al., 2007a, b; Nick et al., 2010), based on the work of Nye (1957) and van der Veen (1998a, b). This model is based on the assumption that calving occurs when surface and basal crevasses meet. Surface and basal crevasse depths are calculated from the balance of forces:

$\sigma_{\mathrm{n}}=2 \tau_{\mathrm{e}} \operatorname{sgn}\left(\tau_{x x}\right)-\rho_{\mathrm{i}} g d+P_{\mathrm{w}}$,

where the result, $\sigma_{\mathrm{n}}$, is the "net stress", which is positive in a crevasse field and negative in unfractured ice (van der Veen, 1998a). The first term on the right-hand side of Eq. (3) represents the opening force of longitudinal stretching, and is adapted from Otero et al. (2010); $\tau_{\mathrm{e}}$ represents effective stress, which is related to the second invariant of the deviatoric stress tensor and which, in 2-D, is defined by Cuffey and Paterson (2010):

$\tau_{\mathrm{e}}^{2}=\tau_{x x}^{2}+\tau_{z x}^{2}$,

where $x$ is the direction of ice flow and $z$ is the vertical. We multiply $\tau_{\mathrm{e}}$ in Eq. (3) by the sign function of longitudinal deviatoric stress $\left(\tau_{x x}\right)$ to ensure crevasse opening is only predicted under longitudinal extension $\left(\tau_{x x}>0\right)$.

The second term on the right-hand side of Eq. (3) represents ice overburden pressure, which leads to creep closure, where $\rho_{\mathrm{i}}$ is the density of glacier ice, $g$ is the force of gravity and $d$ is depth through the ice.

The final term in Eq. (3) is water pressure $\left(P_{\mathrm{w}}\right)$, which acts to open crevasses when present. In basal crevasses, $P_{\mathrm{w}}$ is controlled by the subglacial hydrological system, and in surface crevasses it is related to the depth of water in the crevasse.

Crevasses will exist wherever $\sigma_{\mathrm{n}}$ is positive, and ice remains intact elsewhere. Evaluating Eq. (3) for both surface and basal crevasses at every node in our model allows us to define "zero contours" which represent the base and top of surface and basal crevasse fields, respectively. The modified crevasse-penetration calving criterion (Nick et al., 2010) 
predicts that calving will occur where and when these zero contours meet. By calculating the crevasse depth criterion as an index at every node, and interpolating the nodal values to find the zero contours (Fig. 3), we arrive at a calving implementation which accounts for changes in stress between surface and interior and which is reasonably insensitive to the model's mesh resolution.

The magnitudes of the force components of Eq. (3) vary greatly between the surface and bed. Specifically, the cryostatic pressure will be much higher at the bed. However, when the terminus is near flotation, high basal water pressure will almost completely counteract this closing force. High basal water pressure is thus an essential condition for significant basal crevasse penetration (van der Veen, 1998a). Because our study focuses specifically on calving dynamics, we make the simplifying assumption that an efficient subglacial drainage system exists near the terminus and thus that there is negligible difference in basal water pressure for any given depth within the region where calving may occur. With this assumption, basal water pressure is simply a function of sea level and bed elevation (van der Veen, 1998a):

$P_{\mathrm{w}}=-\rho_{\mathrm{w}} g z$

where $z$ is the $z$ coordinate, which is negative below sea level.

Water pressure is essential for basal crevasse penetration, but it may also be significant in surface crevasses (Benn et al., 2007b). The process of "hydrofracturing" by water in surface crevasses is believed to have been a critical factor in the collapse of the Larsen B Ice Shelf (Scambos et al., 2003). However, while water in surface crevasses may be important, it is extremely difficult to quantify. The relationship between surface melt rate and crevasse water depth depends on the distribution, shape and depth of crevasses, and melting and refreezing on crevasse walls, as well as potential drainage of water from crevasses into englacial, subglacial or proglacial water bodies. As such, it is currently impossible to estimate even an order of magnitude for crevasse water depth at Store in summer. However, outside the 3-month summer melt season, surface crevasses must be assumed to be dry.

Modelling calving in a 2-D continuum model involves some implicit assumptions which may affect the accuracy of the calving criterion presented above. Firstly, the implementation of valley sidewall friction assumes that the calving terminus runs straight from one side of the valley to the other. However, Store's terminus is usually arcuate in shape, with the centreline being further advanced in the fjord than the sidewalls. Thus, our implementation will overestimate lateral drag at the terminus. Secondly, by assuming a constant temperature of $-10^{\circ} \mathrm{C}$ throughout the glacier, we neglect temperature-dependent variations in viscosity and thus the stress field. Finally, Eq. (3) slightly overestimates ice overburden pressure by assuming constant bulk density within the glacier. In fact, the presence of a crevasse field may significantly reduce bulk density; this represents a positive feed-

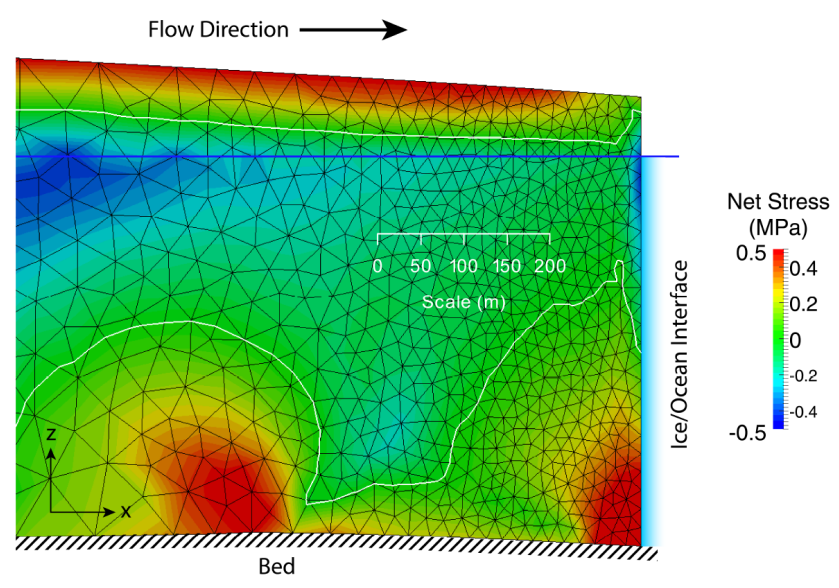

Figure 3. The terminus of the flow line mesh of Store Glacier. White line indicates the net stress $\left(\sigma_{\mathrm{n}}\right)$ zero contour for both surface and basal crevasses. Net stress ( $\mathrm{MPa}$ ) is $>0$ where crevasses exists and $<0$ in solid and unfractured ice. Calving occurs in the model when the surface and basal zero contours meet. The blue line indicates sea level.

back whereby the growth of a crevasse field reduces ice overburden pressure, leading to further crevasse deepening.

For the reasons outlined above, we expect our model to slightly underestimate the penetration of surface and basal crevasses near the present terminus position. As such, we apply a constant scaling factor of 1.075 to the effective stress term in Eq. (3). This scaling procedure is equivalent to the assumed presence of water in crevasses throughout the year in earlier work (Nick et al., 2010; Vieli and Nick, 2011). We note, in this context, that for a typical value of effective stress $\left(\tau_{\mathrm{e}}=300 \mathrm{kPa}\right)$, our $7.5 \%$ scaling factor equates to just $2.3 \mathrm{~m}$ water depth added to crevasses. As there are several factors, aside from water depth, which may explain why the calving criterion does not predict full crevasse penetration exactly at the observed terminus location, we consider the scaling factor to simply be a tunable parameter, encompassing the above processes, and which we keep constant. A more robust treatment of the issues outlined above will most likely require a 3-D model for calving.

\subsection{Model forcing}

We investigate the calving dynamics of Store in three stages. First, we set up a baseline run in which flow is affected only by a seasonal variation in basal traction. We then explore the glacier's response to (1) undercutting of ice front by submarine melting in summer and (2) buttressing of the ice front by rigid mélange in winter. The aim of these numerical experiments (henceforth referred to as experiment 1 ) is to identify which forcing has the greatest influence on the glacier's flow, and the outcome represents a "present-day" simulation in which the glacier's frontal position varies seasonally as observed under current climatic conditions. Finally, we perform 
perturbation experiments by altering mélange and submarine melt forcing in terms of their magnitude and duration. This set of experiments (experiment 2) investigates the response of Store to changes at its calving ice front in a warming climate.

\subsubsection{Submarine melting}

Time-lapse photography shows a meltwater plume at the central section of the terminus of Store in summer months (Chauché et al., 2014). Because the location of this plume coincides with the terminus position in our model, we apply summer melt rates at the calving front which vary linearly from $8 \mathrm{~m} \mathrm{~d}^{-1}$ at the base to $0 \mathrm{~m} \mathrm{~d}^{-1}$ at sea level. This melt distribution is a simplification of the one found by $\mathrm{Xu}$ et al. (2013), who used MITgcm to investigate plume-induced ice front melting at Store, based on previous estimates of fjord water temperature (Rignot et al., 2010) and subglacial meltwater discharge (van Angelen et al., 2012). Their results suggest an average melt rate across the entire face of $3.6 \mathrm{~m} \mathrm{~d}^{-1}$ in summer, with a local maximum at the base of the plume of $8 \mathrm{md}^{-1}$. Because subglacial discharge is strongly influenced by surface runoff in summer months, we assume, for the sake of simplicity, that no submarine melting occurs in winter. If and when the floating tongue exists during the melt season, we apply a bottom melt rate of 1/10th of that applied on the vertical face, based on the "geometrical scale factor" proposed by Jenkins (2011).

In experiment 1 , ice front melting is assumed to occur at a constant rate from the start of June until the end of August, as $>90 \%$ of all surface runoff in the Store catchment occurs over this period. In experiment 2 , we investigate the effects of increasing summer melt rates by a factor of 1.5 and 2 , and increasing its duration by 33 and $66 \%$.

\subsubsection{Mélange backstress}

We simulate the effect of mélange backstress by applying an external pressure on the calving terminus in addition to that exerted by the sea (Fig. 4). The applied pressure is similar to that found by Walter et al. (2012) from a force-balance study of Store, based on the observed speedup of the glacier following mélange collapse. Their results show that the mélange yields a supporting pressure equivalent to a backstress of 30$60 \mathrm{kPa}$ acting on the entire face of the terminus. In reality, this stress is applied only through the thickness of the mélange, a property not measured by Walter et al. (2012). To obtain a realistic forcing scenario at the calving front of our model, we convert Walter et al.'s backstress $\left(\sigma_{\mathrm{fb}}\right)$ into an equivalent mélange-glacier contact pressure:

$\sigma_{\mathrm{sik}}=\sigma_{\mathrm{fb}} \frac{H_{\mathrm{term}}}{H_{\mathrm{sik}}}$

where $H_{\text {term }}$ and $H_{\text {sik }}$ are the thicknesses of the glacier terminus and the mélange, respectively.

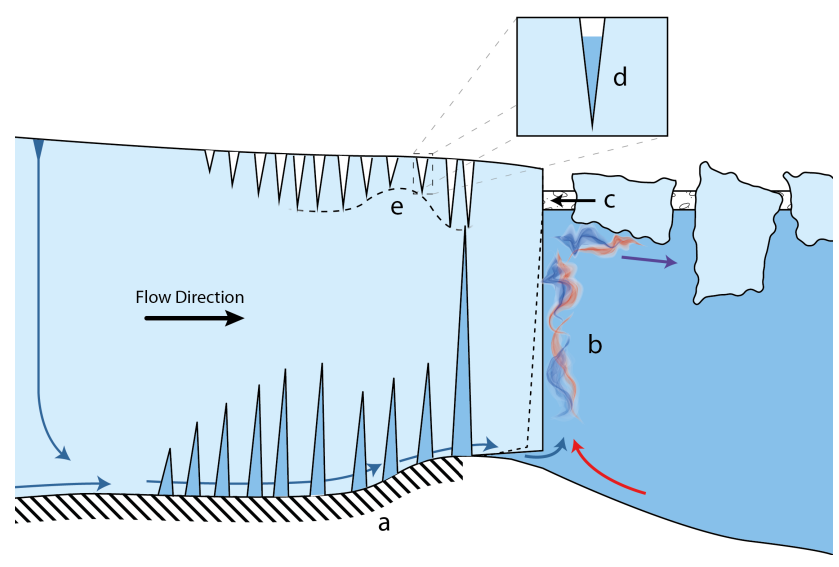

Figure 4. Schematic diagram showing proximal and distal processes affecting calving. (a) Varying basal friction $\left(\tau_{\mathrm{b}}\right)$ affects the stress field in the glacier. (b) Changing fjord water temperatures and subglacial water flux affect the rate of submarine melting of the calving face and floating tongue (when present). (c) The seasonal formation of mélange provides a buttressing force which suppresses surface crevasse depth and thus calving. (d) Surface melt water in crevasses causes hydrofracturing, which acts to deepen surface crevasses. (e) Glacier geometry exerts a strong influence on crevasse field depth: compressional forces on the stoss side of Store's pinning point suppress the depth of crevasses, while rapid loss of basal traction on the lee side deepen them.

In experiment 1 , we take the midpoint of the range estimated by Walter et al. (2012) (45 kPa), acting over a mélange thickness of $75 \mathrm{~m}$, as estimated from laser altimeter data collected by NASA's Operation IceBridge (https://espo.nasa. gov/missions/oib/). Based on the work of Howat et al. (2010), we assume mélange to be present and rigid from the start of February until the end of May and absent from June to January. In experiment 2 , we investigate the effect of reducing mélange strength by 25 and $50 \%$ and its duration by 33 and $66 \%$.

\section{Results}

\subsection{Baseline run}

The baseline configuration of our model includes only one seasonal effect: the prescribed sinusoidal variation in the basal friction parameter between winter and summer values. The result is a slight increase in flow speed at the terminus, from a minimum of $4700 \mathrm{~m} \mathrm{a}^{-1}$ in winter to a maximum of $4900 \mathrm{~m} \mathrm{a}^{-1}$ in summer (Fig. 5b). When the calving criterion is implemented, calving activity is periodic and characterised by $80-90 \mathrm{~m}$ bergs breaking off with a frequency of one per 8.7 days (Fig. 5a). Terminus velocity increases when calving occurs and is reduced afterwards as the front advances. The amplitude of these velocity fluctuations is about $200 \mathrm{~m} \mathrm{a}^{-1}$ (Fig. 5b), a similar magnitude to the seasonal effect of vary- 


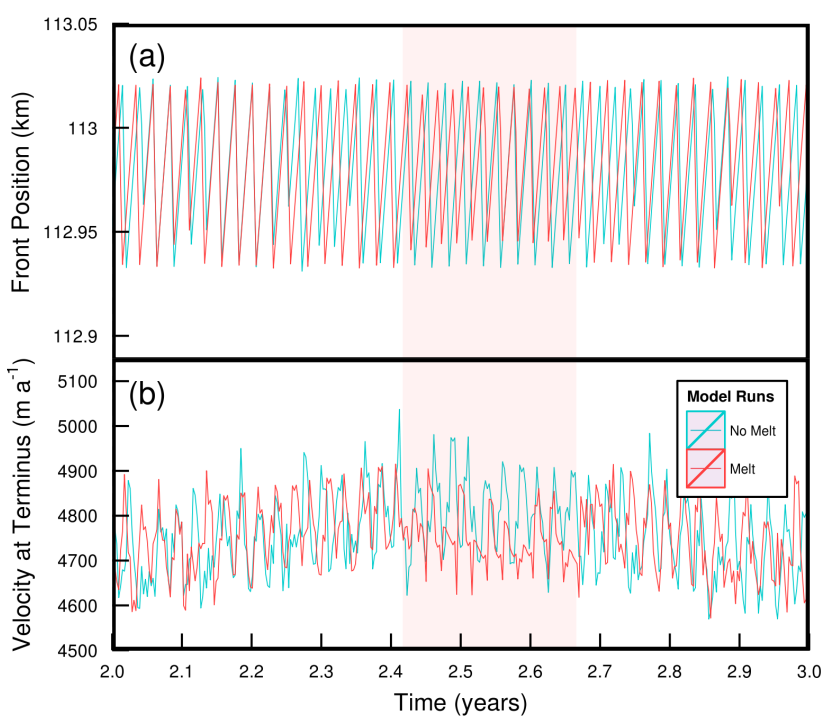

Figure 5. Plots showing variations in terminus position (a) and velocity (b) over the course of a year for the baseline model run (blue line) and a run with submarine melting applied (red line). Red shading indicates melt season. The saw-toothed pattern in both panels is a result of calving.

ing basal friction, indicating that the position of the calving front has a strong influence on terminus velocity. However, the terminus position varies less than $100 \mathrm{~m}$ through the entire simulation and there is no discernible seasonality of the glacier's frontal position. This shows that the observed seasonal advance and retreat of the calving front cannot be attributed to seasonal variation in basal friction.

\subsection{Experiment 1}

To attain a realistic "present-day" simulation, we start by adding submarine melting, as described above, with rates up to $8 \mathrm{~m} \mathrm{~d}^{-1}$ from June to August. This forcing slightly increases the frequency and reduces the magnitude of calving events, though the overall terminus position varies only negligibly (Fig. 5a). Terminus velocity during the melt season is slightly suppressed compared with the melt-free simulation (Fig. 5b). This experiment suggests that neither seasonal variability in basal dynamics nor submarine melting explains the seasonal calving dynamics observed at Store. Only when the stabilising effect of mélange buttressing is included does our model respond with significant frontal advance and retreat. Figure 6 shows the evolution of calving terminus position through time for each of the two seasonal forcings as well as the combined effect.

In our model, the formation of the mélange triggers the immediate formation of a floating ice tongue which advances into the fjord. The terminus advances by $1300 \mathrm{~m}$ between February and May, while the mélange is present, and begins to retreat rapidly when the mélange disappears, irrespective

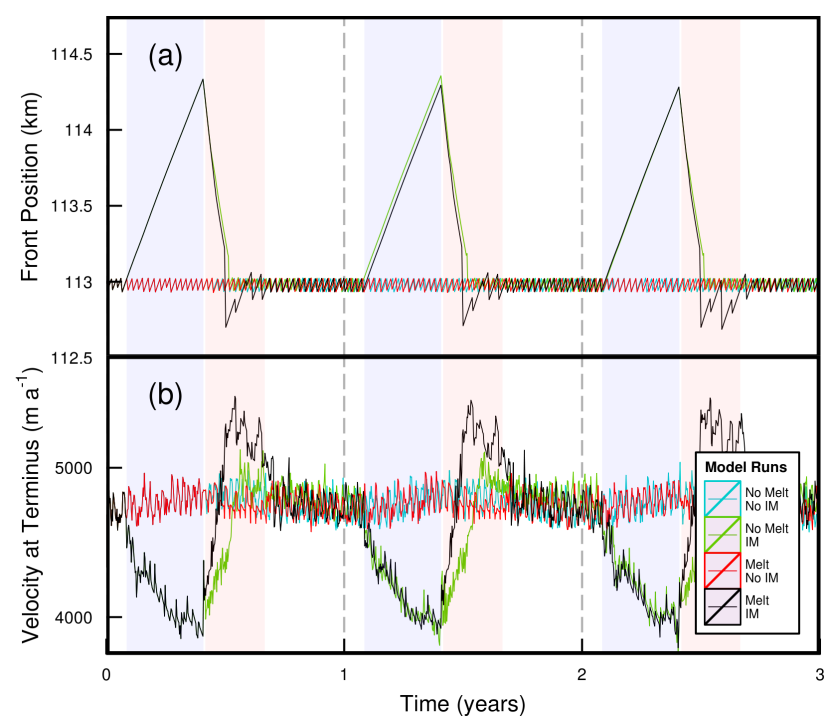

Figure 6. Plots showing changes in calving terminus position (a) and velocity (b) during a 3-year period within a 40-year-long stable simulation, with coloured solid lines illustrating the effect of four different combinations of melting and ice mélange perturbation. Blue and red shading indicates mélange and melt season, respectively.

of whether or not submarine melting is applied (Fig. 6). Figure 7 shows the evolution of the floating tongue through the mélange season. As the floating tongue advances, both the surface and basal crevasse fields are suppressed near the terminus. Note that the surface elevation rises as the floating tongue extends into the fjord, indicating that the dynamic regime near the grounding line is forcing the terminus below flotation level. This is only overcome once the floating tongue is long enough to exert sufficient upward bending moment on the grounding line. Once significant upward bending is exerted, this is manifested as a suppression of surface crevasse field, clearly visible in Fig. 7.

When the mélange effect is combined with submarine melting, the collapse of the floating tongue is followed by a further $250 \mathrm{~m}$ retreat beyond the stable terminus position at $113 \mathrm{~km}$. After this retreat, the terminus slowly readvances through the melt season to $113 \mathrm{~km}$, where it remains, calving periodically, until the mélange forms during the following winter.

Our simulations in this experiment demonstrate a strong correlation between terminus position and velocity. Seasonal dynamics imposed by changing basal friction (Fig. 5) are dwarfed by the deceleration which occurs when the floating ice tongue develops and advances (Fig. 6). The dynamic effect of this slowdown is transmitted up to $30 \mathrm{~km}$ inland (Fig. 8a). During the mélange season, surface velocity is reduced and thickness increases slightly (Fig. 8b) between $90 \mathrm{~km}$ and the terminus. Following mélange collapse, velocity immediately rebounds to values similar to those prior to 


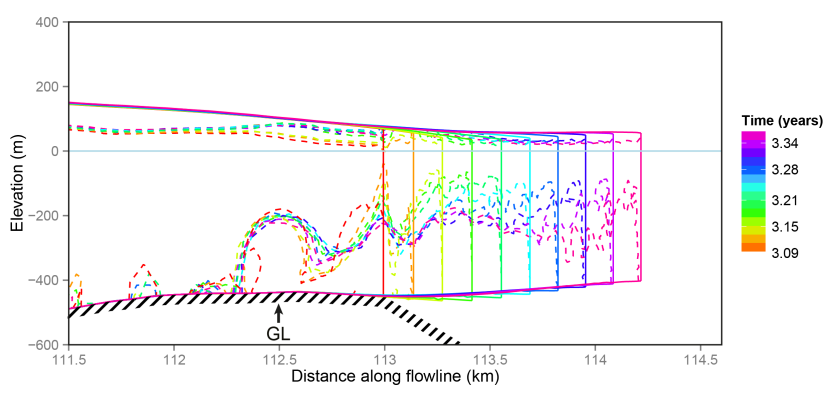

Figure 7. Sequential profiles of Store Glacier during advance of its calving terminus due to mélange backstress. As the floating tongue advances from the grounding line (marked GL), it rises upwards due to buoyant forces, which also act to close surface crevasses near the grounding line. This indicates that flow dynamics at the grounding line are forcing the terminus below flotation.

the mélange formation, and this speedup is followed by a gradual deceleration through the rest of the year. Interestingly, surface velocity at $85 \mathrm{~km}$ is consistently faster throughout the seasonal cycle than its 1 January value, peaking at $7.5 \%$ faster halfway through the year. Figure $8 \mathrm{~b}$ also indicates slight thickening upstream and thinning downstream of this location, which coincides with a significant basal pinning point and large surface slopes as the glacier flows into a deep basal trough (Fig. 2).

The outcome of experiment 1 is a seasonally variable calving model of Store which is in overall good agreement with observations (Howat et al., 2010; Walter et al., 2012). The stable position adopted by the modelled terminus $(113 \mathrm{~km})$ following the summer melt season matches the observed summer terminus position. As observed, the modelled terminus retreats rapidly soon after mélange has collapsed in the fjord. The total seasonal variability in modelled front position $(1.3 \mathrm{~km})$ is in good agreement with that observed by Howat et al. (2010), as well as time-lapse imagery collected by the Extreme Ice Survey (www.eis.com), which shows that the frontal position of Store can vary by more than $\sim 1 \mathrm{~km}$ between summer and winter (J. Box, personal communication, 2014).

\subsection{Experiment 2}

In this experiment, we perturb the stable "present-day" simulation obtained in experiment 1 in order to investigate the response of Store to climate change. We specifically investigate the glacier's response to changes in mélange buttressing and submarine melting because these forcing factors are poorly understood.

When mélange strength is reduced to $75 \%$ of its baseline value (Fig. 9a-c, green lines), the floating tongue does not begin to form until halfway through the mélange season. As a result, the maximum length of the tongue is reduced from 1.3 to $0.7 \mathrm{~km}$. When mélange strength is further re-

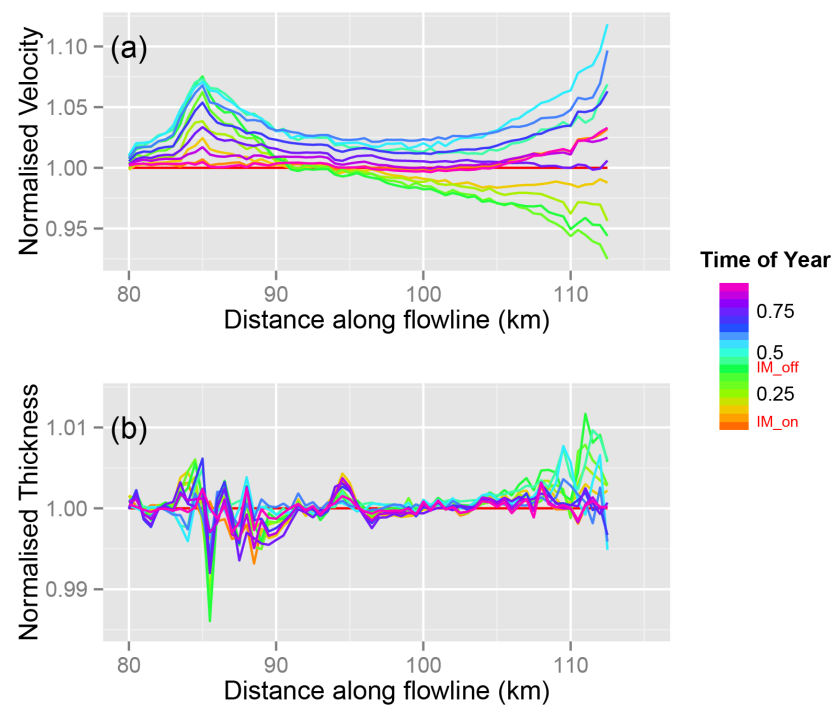

Figure 8. Plots showing velocity (a) and thickness (b) perturbations through a single calendar year. Line colour indicates time of year. Velocity and thickness have been normalised against their 1 January values.

duced to $50 \%$ (Fig. 9a-c, red lines), no floating tongue forms in spring, though there remains a clear change in calving dynamics throughout the mélange season. These results suggest that any future climate-related reduction in the strength of mélange may significantly affect the calving dynamics and seasonality of Store.

Reducing the duration of the mélange season to $66 \%$ (Fig. 9b) limits the length of the floating tongue to $0.8 \mathrm{~km}$ for the $45 \mathrm{kPa}$ case. However, reduction to $33 \%$ (Fig. 9c) has no further effect on calving dynamics, and the floating tongue continues to advance for a month following mélange break-up. This is a surprising result, which suggests that the floating tongue is at least temporarily self-stabilising. In the $75 \%$ mélange strength case, when season duration is reduced to $66 \%$ (Fig. 9b, green line), the floating tongue begins to advance slightly sooner and thus the final length is slightly higher. However, no floating tongue forms when season duration is further reduced to $33 \%$ (Fig. 9c, green line).

An increase in the duration of submarine melting, by 33 and $66 \%$ (Fig. 9e and f, respectively), leads to more rapid collapse of the floating tongue, though in no case does the tongue collapse while rigid mélange is still present. As in experiment 1 (Fig. 6), submarine melting has an appreciable effect on the calving dynamics of the grounded terminus in late summer. As such, a longer submarine melt season leads to a longer period of larger, less frequent calving events and a retreat in average terminus position. The response of the modelled terminus to increasing melt magnitude, on the other hand, appears somewhat stochastic. It should be noted, however, that the positions shown in Figs. 5, 6 and 9 represent the terminus at the surface, which is able to advance into the 


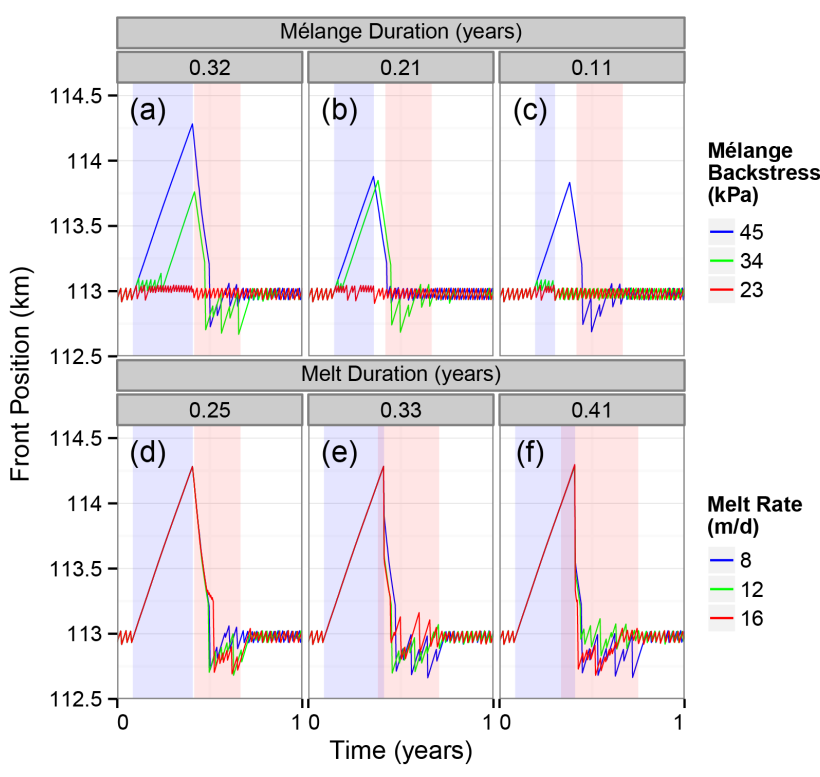

Figure 9. Plots showing terminus position through 1 year for varying mélange season duration $(\mathbf{a}-\mathbf{c})$ and melt season duration $(\mathbf{d}-\mathbf{f})$. Durations of mélange and melt season are indicated by blue and red shading, respectively. Line colour indicates varying magnitude of melt rate and mélange backstress. The blue line in panels (a) and (d) represent the baseline model from experiment 1 (Fig. 6). Changing panels and line colours indicate perturbations under progressively warmer climate scenarios.

fjord when undercutting takes place, due to the fact that the glacier's topography exerts a control on the position of the grounding line. Broadly speaking, the calving dynamics are, according to this model, relatively unaffected by increasing melt magnitude. In even the most severe "warming climate" scenario, with melt rate double that of present-day values and duration increased from 3 to 5 months, the modelled terminus remains stable.

\section{Discussion}

The results of our modelling experiments shed new light on marine-terminating glacier dynamics and the calving mechanism. The calving dynamics of the modelled glacier vary significantly through the year (experiment 1, Fig. 6), from high-frequency (8.7 days), low-magnitude $(\sim 80 \mathrm{~m})$ calving events when no seasonal forcing is applied to complete cessation of calving during the mélange season, with rapid retreat following mélange collapse, and seemingly stochastic calving behaviour during the melt season. This behaviour is in good overall agreement with year-round observation of Store (N. Chauché, personal communication, 2014). Our model captures two important aspects of Store's behaviour. Seasonally, Store's terminus position is highly sensitive to external perturbation. However, on interannual timescales,
Store's calving dynamics are stable, and the terminus position remains fairly constant (Howat et al., 2010).

In our model, the seasonal advance and retreat is specifically related to a floating tongue, which forms during winter in response to the buttressing effect of rigid mélange (Figs. 6,7) and breaks apart once the buttressing effect of the mélange disappears. This finding provides theoretical understanding for the observed temporal correlation between mélange break-up and frontal retreat at Store and other glaciers in the Uummannaq region (Howat et al., 2010), as well as Jakobshavn Isbræ (Amundson et al., 2010) farther south, and glaciers such as Kangerdlugssuaq and DaugaardJensen on the east coast (Seale et al., 2011). Our results from experiment 2 suggest that the estimate of Walter et al. (2012) of a mélange strength of 30-60 kPa is most likely correct, and that any future climate-driven reduction in mélange strength or thickness could significantly impact the seasonal dynamics of Store (Fig. 9).

When we isolated the effect of submarine melting of the ice front (experiment 1, Fig. 5), we found a slight increase in calving frequency, an associated decrease in calving event size, and a slight dampening of the glacier's velocity response to calving events. However, the overall effect of submarine melting alone was minimal. Only when combined with mélange forcing was submarine melting capable of significantly affecting calving dynamics (Fig. 6). This suggests that some process during the mélange season preconditions the glacier for slight instability later in the season. Potentially, the upward bending associated with the formation of the floating tongue (Fig. 7) changes the glacier geometry near the grounding line such that it is more susceptible to the effect of undercutting by submarine melting.

Despite doubling melt rates and increasing melt duration by $66 \%$ in experiment 2 (Fig. 9), the terminus of Store remained stable at $113 \mathrm{~km}$, suggesting that there is no direct link between submarine undercutting and longer-term calving stability of the grounded terminus at present. This result contradicts previous work suggesting that undercutting of the terminus promotes calving (Motyka et al., 2003; Rignot et al., 2010) by intensifying extensional stresses near the terminus (O'Leary and Christoffersen, 2013). We propose, however, that this apparent contradiction is a feature specific to Store, due to the strong stabilising influence of topography.

The location of the terminus of Store coincides with a significant basal pinning point (Fig. 2), as well as a "bottleneck" in the fjord width (Fig. 1). The combined effect of these topographical features is to significantly affect the stress field and crevasse depth (Fig. 4). The suppression of crevasses penetration depth at the stoss side of the basal pinning point at the terminus exceeds the deepening of crevasses in response to undercutting of the ice front by submarine melting. As such, the latter alone cannot cause the front to retreat in this case. This suggests that, as long as the melt rate is less than the rate of ice delivery to the front, the terminus position of Store will be relatively insensitive to the rate of ice front melting. Thus, 
the rate of iceberg production will be solely controlled by the velocity at the terminus. The topographic setting of Store explains why this glacier remained stable during a period when others in the same region experienced rapid retreats (Howat et al., 2010) and, more generally, why neighbouring glaciers are often observed to respond asynchronously to similar climate forcing (Moon et al., 2012).

Inland of Store's stable frontal pinning point is a $28 \mathrm{~km}$ long overdeepening reaching $950 \mathrm{~m}$ below sea level (Fig. 2), which could make Store susceptible to sudden retreat, i.e. if the terminus becomes ungrounded from its current pinning point at $113 \mathrm{~km}$. We found that, by forcing the model with unphysically large values for submarine melt rate (not shown), we were able to force the terminus back off its pinning point, which led to rapid retreat through this trough. However, none of our climate forcing scenarios were able to trigger such a retreat, which suggests that the current configuration of Store is stable and will most likely remain so in the near future.

As laid out above, our model is capable of reproducing the flow and seasonal calving dynamics of Store simply by perturbing the backstress exerted by mélange and the rate of submarine melting. Our model excludes the effect of water in surface crevasses, which may conceivably affect calving due to hydrofracture if water levels are high (Benn et al., 2007a). Although recent work included this effect (Nick et al., 2010), we ignore it because high-resolution images captured in repeat surveys of Store with an unmanned aerial vehicle in July 2013 detected water in only a small number of surface crevasses near the terminus (Ryan et al., 2014). Although we cannot exclude the possibility that undetected water is contributing to crevasse penetration, it is not necessary to invoke this process to explain the observed behaviour of Store. This exclusion of hydrofracturing is a useful model simplification, as it is difficult and potentially impossible to accurately estimate the depth of water in crevasses. The latter would require knowledge of surface meltwater production as well as the number and size of surface crevasses, which is infeasible with the type of model used here.

Although our model captures the flow and seasonal calving dynamics of Store in a realistic manner, it is important to note that the outcome of our study is specifically limited to this glacier and that multiyear dynamics remain to be fully investigated. We use inverse methods to determine basal traction, rather than a hydrological model; this ensures that the flow field matches observations, allowing us to focus on processes at the terminus. However, prescribing basal traction means we are unable to investigate its interannual evolution in response to dynamic thinning, rising sea level or hydrological processes. The difficulty of implementing realistic hydrological routing in a flow line model suggests that only a 3-D model will be fully capable of representing these processes.

It is useful, at this point, to compare the development of time-evolving models for calving with recent developments in the implementation of grounding line dynamics. The lack of consistency of grounding line treatment in ice flow models was raised by Vieli and Payne (2005), and this issue has since received a great deal of attention from the ice sheet modelling community. A comprehensive intercomparison study, MISMIP (Pattyn et al., 2012), compared the ability of various 2-D ice flow models to simulate grounding line dynamics, before MISMIP3d (Pattyn et al., 2013) did the same for 3-D models. Similarly, we hope that the 2-D model presented here will guide the future development of full 3-D time-evolving models for calving.

Finally, we note that, in terms of accounting for the feedback between crevasse formation and bulk density and flow characteristics, a damage mechanics approach may prove useful (Pralong and Funk, 2005; Borstad et al., 2012). A counterpart study to this one by Krug et al. (2014) attempts to couple a damage model with a calving model for Helheim Glacier using Elmer/Ice.

\section{Conclusions}

Here we have presented results from a seasonally transient but interannually stable calving model of Store Glacier in West Greenland. The calving numerics in our model differ from previous implementations of the crevasse depth criterion (Nick et al., 2010; Vieli and Nick, 2011; Cook et al., 2014) in that the balance of crevasse opening and closing forces is calculated through the entire thickness, not just at the boundaries, meaning that changes through depth are taken into account. In agreement with recent related work (Nick et al., 2010), we find that the inclusion of basal crevasses in the calving criterion is important. We propose the addition of a new divergence term to the Stokes equations, which is not only practical but most likely essential for accurate simulation of glaciers in 2-D flow line models. We also find that the frequently assumed presence of water in surface crevasses is not necessary for seasonal calving dynamics at Store.

We find that basal traction varies very little between winter and summer; basal lubrication by surface meltwater is therefore unlikely to play an important role in the seasonal advance and retreat of the ice front. This does not imply, however, that calving and flow dynamics are not strongly coupled. Our results indicate a strong correlation between terminus position and velocity (Figs. 5, 6). The deceleration which results from advance of the floating tongue is transmitted up to $30 \mathrm{~km}$ inland (Fig. 8). This finding supports previous studies which found that dynamic change at Helheim Glacier (Nick et al., 2009) and Jakobshavn Isbræ (Joughin et al., 2012) were triggered at the terminus.

A key outcome from this study is that the buttressing pressure from rigid mélange is principally responsible for observed seasonal advance and retreat. However, sensitivity analysis revealed that, in a warming climate, reduction in mélange strength or duration could prevent Store from ad- 
vancing a floating tongue in winter. The model also indicates that submarine melting has only a limited effect on calving dynamics and that even large changes to melt rates in the future are unlikely to destabilise the terminus of Store. We propose that Store's highly stable terminus configuration is due to its topographic setting, being located at both a basal pinning point and a "bottleneck" in fjord width. We also find, however, that behind this basal pinning point, Store flows across a very large trough, reaching $950 \mathrm{~m}$ below sea level and extending $28 \mathrm{~km}$ inland from the current grounding line. This suggests that, were the terminus to be forced to retreat from its current pinning point, further retreat may be rapid and sudden, of a similar magnitude to that experienced by Jakobshavn Isbræ, which resulted in a sustained increase of ice flux and contribution to sea level rise (Joughin et al., 2012).

\section{The Supplement related to this article is available online at doi:10.5194/tc-8-2353-2014-supplement.}

Acknowledgements. This study was funded by the Natural Environment Research Council through a $\mathrm{PhD}$ studentship (grant no. NE/K500884/1) to J. Todd and research grant (NE/K005871/1) to P. Christoffersen. We thank Thomas Zwinger, Peter Råback and Olivier Gagliardini for help with the Elmer/Ice model, Michiel van den Broeke for providing RACMO climate data, Alun Hubbard and Jason Box for useful discussions related to Store Glacier. We are grateful to Chris Borstad and an anonymous reviewer for useful feedback during the review process.

Edited by: E. Larour

\section{References}

Amundson, J. M., Truffer, M., Lüthi, M. P., Fahnestock, M., West, M., and Motyka, R. J.: Glacier, fjord, and seismic response to recent large calving events, Jakobshavn Isbræ, Greenland, Geophys. Res. Lett., 35, L22501, doi:10.1029/2008GL035281, 2008.

Amundson, J. M., Fahnestock, M., Truffer, M., Brown, J., Lüthi, M. P., and Motyka, R. J.: Ice mélange dynamics and implications for terminus stability, Jakobshavn Isbræ, Greenland, J. Geophys. Res., 115, F01005, doi:10.1029/2009JF001405, 2010.

Benn, D. I., Hulton, N. R. J., and Mottram, R. H.: "Calving laws", "sliding laws" and the stability of tidewater glaciers, Ann. Glaciol., 46, 123-130, 2007a.

Benn, D. I., Warren, C. R., and Mottram, R. H.: Calving processes and the dynamics of calving glaciers, Earth-Sci. Rev., 82, 143179, 2007b.

Borstad, C. P., Khazendar, A., Larour, E., Morlighem, M., Rignot, E., Schodlok, M. P., and Seroussi, H.: A damage mechanics assessment of the Larsen B ice shelf prior to collapse: Toward a physically-based calving law, Geophys. Res. Lett., 39, L18502, doi:10.1029/2012GL053317, 2012.
Box, J. E., Bromwich, D. H., Veenhuis, B. A., Bai, L., Stroeve, J. C., Rogers, J. C., Steffen, K., Haran, T., and Wang, S. H.: Greenland ice sheet surface mass balance variability (1988-2004) from calibrated polar MM5 output, J. Climate, 19, 2783-2800, 2006.

Chauché, N., Hubbard, A., Gascard, J.-C., Box, J. E., Bates, R., Koppes, M., Sole, A., Christoffersen, P., and Patton, H.: Iceocean interaction and calving front morphology at two west Greenland tidewater outlet glaciers, The Cryosphere, 8, 14571468, doi:10.5194/tc-8-1457-2014, 2014.

Christoffersen, P., Mugford, R. I., Heywood, K. J., Joughin, I., Dowdeswell, J. A., Syvitski, J. P. M., Luckman, A., and Benham, T. J.: Warming of waters in an East Greenland fjord prior to glacier retreat: mechanisms and connection to large-scale atmospheric conditions, The Cryosphere, 5, 701-714, doi:10.5194/tc5-701-2011, 2011.

Cook, S., Rutt, I. C., Murray, T., Luckman, A., Zwinger, T., Selmes, N., Goldsack, A., and James, T. D.: Modelling environmental influences on calving at Helheim Glacier in eastern Greenland, The Cryosphere, 8, 827-841, doi:10.5194/tc-8-827-2014, 2014.

Cuffey, K. and Paterson, W.: The physics of glaciers, Academic Press, 4th Edn., available at: http://books.google. co.uk/books?hl=en\&lr=\&id=Jca2v1u1EKEC\&oi=fnd\&pg= PP2\&dq=physics+of+glaciers+4th\&ots=KKKU11nijd\&sig= sEDIZ7UJFArX1YdYQXtLkH3j5Ms (5 May 2014), 2010.

Enderlin, E. M., Howat, I. M., Jeong, S., Noh, M.-J., van Angelen, J. H., and van den Broeke, M. R.: An Improved Mass Budget for the Greenland Ice Sheet, Geophys. Res. Lett., 41, 866-872, doi:10.1002/2013GL059010, 2014.

Ettema, J., van den Broeke, M. R., van Meijgaard, E., van de Berg, W. J., Bamber, J. L., Box, J. E., and Bales, R. C.: Higher surface mass balance of the Greenland ice sheet revealed by highresolution climate modeling, Geophys. Res. Lett., 36, L12501, doi:10.1029/2009GL038110, 2009.

Favier, L., Gagliardini, O., Durand, G., and Zwinger, T.: A threedimensional full Stokes model of the grounding line dynamics: effect of a pinning point beneath the ice shelf, The Cryosphere, 6, 101-112, doi:10.5194/tc-6-101-2012, 2012.

Gagliardini, O., Durand, G., Zwinger, T., Hindmarsh, R. C. A., and Le Meur, E.: Coupling of ice-shelf melting and buttressing is a key process in ice-sheets dynamics, Geophys. Res. Lett., 37, L14501, doi:10.1029/2010GL043334, 2010.

Gagliardini, O., Zwinger, T., Gillet-Chaulet, F., Durand, G., Favier, L., de Fleurian, B., Greve, R., Malinen, M., Martín, C., Råback, P., Ruokolainen, J., Sacchettini, M., Schäfer, M., Seddik, H., and Thies, J.: Capabilities and performance of Elmer/Ice, a newgeneration ice sheet model, Geosci. Model Dev., 6, 1299-1318, doi:10.5194/gmd-6-1299-2013, 2013.

Gillet-Chaulet, F., Gagliardini, O., Seddik, H., Nodet, M., Durand, G., Ritz, C., Zwinger, T., Greve, R., and Vaughan, D. G.: Greenland ice sheet contribution to sea-level rise from a new-generation ice-sheet model, The Cryosphere, 6, 1561-1576, doi:10.5194/tc-6-1561-2012, 2012.

Gladstone, R. M., Lee, V., Rougier, J., Payne, A. J., Hellmer, H., Le Brocq, A., Shepherd, A., Edwards, T. L., Gregory, J., and Cornford, S. L.: Calibrated prediction of Pine Island Glacier retreat during the 21 st and 22nd centuries with a coupled flowline model, Earth Planet. Sc. Lett., 333-334, 191-199, doi:10.1016/j.eps1.2012.04.022, 2012. 
Hanna, E.: Runoff and mass balance of the Greenland ice sheet: 1958-2003, J. Geophys. Res., 110, D13108, doi:10.1029/2004JD005641, 2005.

Holland, D. M., Thomas, R. H., de Young, B., Ribergaard, M. H., and Lyberth, B.: Acceleration of Jakobshavn Isbræ triggered by warm subsurface ocean waters, Nat. Geosci., 1, 659-664, 2008.

Howat, I., Joughin, I., Tulaczyk, S., and Gogineni, S.: Rapid retreat and acceleration of Helheim Glacier, east Greenland, Geophys. Res. Lett., 32, L22502, doi:10.1029/2005GL024737, 2005.

Howat, I., Joughin, I., and Scambos, T.: Rapid changes in ice discharge from Greenland outlet glaciers, Science, 315, 1559-1561, doi:10.1126/science.1138478, 2007.

Howat, I. M., Box, J. E., Ahn, Y., Herrington, A., and McFadden, E. M.: Seasonal variability in the dynamics of marineterminating outlet glaciers in Greenland, J. Glaciol., 56, 601613,2010

Howat, I. M., Negrete, A., and Smith, B. E.: The Greenland Ice Mapping Project (GIMP) land classification and surface elevation data sets, The Cryosphere, 8, 1509-1518, doi:10.5194/tc-81509-2014, 2014.

IPCC: Climate Change 2013: The Physical Science Basis. Contribution of Working Group I to the IPCC Fifth Assessment Report of the Intergovernmental Panel on Climate Change, edited by: Stocker, T. F., Qin, D., Plattner, G.-K., Tignor, M., Allen, S. K., and Boschung, J., Vol. AR5, Cambridge University Press, Cambridge, United Kingdom and New York, NY, USA, 2013.

Jenkins, A.: Convection-Driven Melting near the Grounding Lines of Ice Shelves and Tidewater Glaciers, J. Phys. Oceanogr., 41, 2279-2294, doi:10.1175/JPO-D-11-03.1, 2011.

Joughin, I., Howat, I. M., Fahnestock, M., Smith, B., Krabill, W., Alley, R. B., Stern, H., and Truffer, M.: Continued evolution of Jakobshavn Isbrae following its rapid speedup, J. Geophys. Res., 113, F04006, doi:10.1029/2008JF001023, 2008.

Joughin, I., Smith, B., Howat, I., and Scambos, T.: MEaSUREs Greenland Ice Velocity: Selected Glacier Site Velocity Maps from InSAR. Boulder, Colorado, USA: NASA DAAC at the National Snow and Ice Data Center, doi:10.5067/MEASURES/CRYOSPHERE/nsidc-0481.001, 2011.

Joughin, I., Smith, B. E., Howat, I. M., Floricioiu, D., Alley, R. B., Truffer, M., and Fahnestock, M.: Seasonal to decadal scale variations in the surface velocity of Jakobshavn Isbrae, Greenland: Observation and model-based analysis, J. Geophys. Res., 117, F02030, doi:10.1029/2011JF002110, 2012.

Joughin, I., Smith, B. E., Shean, D. E., and Floricioiu, D.: Brief Communication: Further summer speedup of Jakobshavn Isbræ, The Cryosphere, 8, 209-214, doi:10.5194/tc-8-209-2014, 2014.

Khan, S. A., Wahr, J., Bevis, M., Velicogna, I., and Kendrick, E.: Spread of ice mass loss into northwest Greenland observed by GRACE and GPS, Geophys. Res. Lett., 37, L06501, doi:10.1029/2010GL042460, 2010.

Krug, J., Weiss, J., Gagliardini, O., and Durand, G.: Combining damage and fracture mechanics to model calving, The Cryosphere, 8, 2101-2117, doi:10.5194/tc-8-2101-2014, 2014.

Luckman, A. and Murray, T.: Seasonal variation in velocity before retreat of Jakobshavn Isbræ, Greenland, Geophys. Res. Lett., 32, L08501, doi:10.1029/2005GL022519, 2005.
MacAyeal, D. R.: The basal stress distribution of Ice Stream E, Antarctica, inferred by control methods, J. Geophys. Res., 97, 595-603, doi:10.1029/91JB02454, 1992.

McNabb, R. W., Hock, R., O’Neel, S., Rasmussen, L. A., Ahn, Y., Braun, M., Conway, H., Herreid, S., Joughin, I., Pfeffer, W. T., Smith, B. E., and Truffer, M.: Using surface velocities to calculate ice thickness and bed topography: a case study at Columbia Glacier, Alaska, USA, J. Glaciol., 58, 1151-1164, 2012.

Moon, T., Joughin, I., Smith, B., and Howat, I.: 21st-century evolution of Greenland outlet glacier velocities, Science, 336, 576578, doi:10.1126/science.1219985, 2012.

Motyka, R., Fahnestock, M., and Truffer, M.: Volume change of Jakobshavn Isbræ, West Greenland: 1985-1997-2007, J. Glaciol., 56, 635-646, 2010.

Motyka, R. J., Hunter, L., Echelmeyer, K. A., and Connor, C.: Submarine melting at the terminus of a temperate tidewater glacier, LeConte Glacier, Alaska, U.S.A., Ann. Glaciol., 36, 5765, doi:10.3189/172756403781816374, 2003.

Nick, F. M., Vieli, A., Howat, I. M., and Joughin, I.: Large-scale changes in Greenland outlet glacier dynamics triggered at the terminus, Nat. Geosci., 2, 110-114, doi:10.1038/ngeo394, 2009.

Nick, F. M., Van der Veen, C. J., Vieli, A., and Benn, D. I.: A physically based calving model applied to marine outlet glaciers and implications for the glacier dynamics, J. Glaciol., 56, 781-794, 2010.

Nye, J. F.: The Distribution of Stress and Velocity in Glaciers and Ice-Sheets, P. Roy. Soc. A, 239, 113-133, doi:10.1098/rspa.1957.0026, 1957.

O'Leary, M. and Christoffersen, P.: Calving on tidewater glaciers amplified by submarine frontal melting, The Cryosphere, 7, 119128, doi:10.5194/tc-7-119-2013, 2013.

Otero, J., Navarro, F. J., Martin, C., Cuadrado, M. L., and Corcuera, M. I.: A three-dimensional calving model: numerical experiments on Johnsons Glacier, Livingston Island, Antarctica, J. Glaciol., 56, 200-214, doi:10.3189/002214310791968539, 2010.

Pattyn, F., Schoof, C., Perichon, L., Hindmarsh, R. C. A., Bueler, E., de Fleurian, B., Durand, G., Gagliardini, O., Gladstone, R., Goldberg, D., Gudmundsson, G. H., Huybrechts, P., Lee, V., Nick, F. M., Payne, A. J., Pollard, D., Rybak, O., Saito, F., and Vieli, A.: Results of the Marine Ice Sheet Model Intercomparison Project, MISMIP, The Cryosphere, 6, 573-588, doi:10.5194/tc6-573-2012, 2012.

Pattyn, F., Perichon, L., Durand, G., Favier, L., Gagliardini, O., Hindmarsh, R. C., Zwinger, T., Albrecht, T., Cornford, S., Docquier, D., Fürst, J. J., Goldberg, D., Gudmundsson, G. H., Humbert, A., Hütten, M., Huybrechts, P., Jouvet, G., Kleiner, T., Larour, E., Martin, D., Morlighem, M., Payne, A. J., Pollard, D., Rückamp, M., Rybak, O., Seroussi, H., Thoma, M., and Wilkens, N.: Grounding-line migration in plan-view marine icesheet models: results of the ice2sea MISMIP3d intercomparison, J. Glaciol., 59, 410-422, 2013.

Pralong, A. and Funk, M.: Dynamic damage model of crevasse opening and application to glacier calving, J. Geophys. Res. B, 110, 1-12, 2005.

Raymond, C.: Shear margins in glaciers and ice sheets, J. Glaciol., 42, 90-102, 1996. 
Rignot, E. and Kanagaratnam, P.: Changes in the velocity structure of the Greenland Ice Sheet, Science, 311, 986-990, doi:10.1126/science.1121381, 2006.

Rignot, E., Koppes, M., and Velicogna, I.: Rapid submarine melting of the calving faces of West Greenland glaciers, Nat. Geosci., 3, 187-191, doi:10.1038/ngeo765, 2010.

Ryan, J. C., Hubbard, A. L., Todd, J., Carr, J. R., Box, J. E., Christoffersen, P., Holt, T. O., and Snooke, N.: Repeat UAV photogrammetry to assess calving front dynamics at a large outlet glacier draining the Greenland Ice Sheet, The Cryosphere Discuss., 8, 2243-2275, doi:10.5194/tcd-8-2243-2014, 2014.

Scambos, T., Hulbe, C., and Fahnestock, M.: Climate-induced ice shelf disintegration in the Antarctic Peninsula, Antarctic Research Series, 79, 79-92, 2003.

Seale, A., Christoffersen, P., Mugford, R. I., and O'Leary, M.: Ocean forcing of the Greenland Ice Sheet: Calving fronts and patterns of retreat identified by automatic satellite monitoring of eastern outlet glaciers, J. Geophys. Res., 116, F03013, doi:10.1029/2010JF001847, 2011.

Sohn, H.-G., Jezek, K. C., and van der Veen, C. J.: Jakobshavn Glacier, west Greenland: 30 years of spaceborne observations, Geophys. Res. Lett., 25, 2699-2702, doi:10.1029/98GL01973, 1998.

Straneo, F., Hamilton, G. S., Sutherland, D. A., Stearns, L. A., Davidson, F., Hammill, M. O., Stenson, G. B., and RosingAsvid, A.: Rapid circulation of warm subtropical waters in a major glacial fjord in East Greenland, Nat. Geosci., 3, 182-186, doi:10.1038/ngeo764, 2010.

Thomas, R. H., Abdalati, W., Frederick, E., Krabill, W. B., Manizade, S., and Steffen, K.: Investigation of surface melting and dynamic thinning on Jakobshavn Isbrae, Greenland, J. Glaciol., 49, 231-239, 2003.

van Angelen, J. H., Lenaerts, J. T. M., Lhermitte, S., Fettweis, X., Kuipers Munneke, P., van den Broeke, M. R., and van Meijgaard, E.: Sensitivity of Greenland Ice Sheet surface mass balance to surface albedo parameterization: a study with a regional climate model, The Cryosphere Discuss., 6, 1531-1562, doi:10.5194/tcd-6-1531-2012, 2012. van den Broeke, M., Bamber, J., Ettema, J., Rignot, E., Schrama, E., van de Berg, W. J., van Meijgaard, E., Velicogna, I., and Wouters, B.: Partitioning recent Greenland mass loss, Science, 326, 984 986, doi:10.1126/science.1178176, 2009.

van der Veen, C.: Fracture mechanics approach to penetration of bottom crevasses on glaciers, Cold Reg. Sci. Technol., 27, 213223, 1998a.

van der Veen, C.: Fracture mechanics approach to penetration of surface crevasses on glaciers, Cold Reg. Sci. Technol., 27, 3147, 1998b.

Vieli, A. and Nick, F.: Understanding and modelling rapid dynamic changes of tidewater outlet glaciers: issues and implications, Surv. Geophys., 32, 437-458, 2011.

Vieli, A. and Payne, A. J.: Assessing the ability of numerical ice sheet models to simulate grounding line migration, J. Geophys. Res., 110, F01003, doi:10.1029/2004JF000202, 2005.

Walter, J. I., Jason, E., Tulaczyk, S., Brodsky, E. E., Howat, I. M., Yushin, A. H. N., and Brown, A.: Oceanic mechanical forcing of a marine-terminating Greenland glacier, Ann. Glaciol., 53, 181$192,2012$.

Weidick, A., Williams, R., and Ferrigno, J.: Satellite Image Atlas of Glaciers of the World: Greenland, USGS, 1995.

Xu, Y., Rignot, E., Fenty, I., Menemenlis, D., and Flexas, M. M.: Subaqueous melting of Store Glacier, west Greenland from three-dimensional, high-resolution numerical modeling and ocean observations, Geophys. Res. Lett., 40, 4648-4653, doi:10.1002/grl.50825, 2013.

Zwally, H. J., Abdalati, W., Herring, T., Larson, K., Saba, J., and Steffen, K.: Surface melt-induced acceleration of Greenland icesheet flow, Science, 297, 218-22, doi:10.1126/science.1072708, 2002 . 